\section{Furman v. Georgia (1972)}

Robert L. Heilbronne

Chicago Neuropsychology Group, Chicago, IL, USA

\section{Definition}

This is the first US Supreme Court case to hold that capital punishment was a violation of the cruel and unusual punishments clause and therefore unconstitutional. William Henry Furman was robbing a person's house and was interrupted when the homeowner arrived. Furman reportedly tried to escape and, while doing so, tripped, which caused the weapon he was carrying to fire killing the homeowner. Furman was tried for murder, found guilty (primarily as a result of his own testimony), and sentenced to death. The US Supreme Court was split five to four in rejecting the imposition of the death penalty. A result could not be agreed upon, but instead the US Supreme Court ruled that utilization of the death penalty in the USA represents "cruel and unusual" punishment, and it violates the Eighth Amendment because it is morally unacceptable to the people of the USA “. . . at this time in their history." Seven of the justices did not object to the death penalty itself as unconstitutional, but, rather, indicated their disapproval of the lack of specific guidelines for indicating when a judge or jury should impose the death penalty and because of the arbitrary and inconsistent manner in which capital punishment was imposed. As a result of this decision, death penalty statutes were rewritten by 35 states to address the problems pointed out in Furman v. Georgia.

\section{Cross-References}

Capital Punishment

> Death Penalty

\section{References and Readings}

Cunningham, M. D., \& Goldstein, A. M. (2003). Sentencing determinations in death penalty cases. In A. Goldstein (Ed.), Handbook of psychology (Forensic psychology, Vol. 11). New Jersey: Wiley.

Furman v. Georgia, 408 U.S. 238 (1972).

Heilbronner, R. L., \& Waller, D. (2008). Neuropsychological consultation in the sentencing phase of capital cases. In R. Denney \& J. Sullivan (Eds.), Clinical neuropsychology in the criminal forensic setting. New York: Guilford Press. 